\title{
The Impact of Peer Relations in the Academic Process among Adolescents
}

\author{
Irma Leka (Peza), PhD Candidate
}

\author{
University of Tirana, Faculty of Social Sciences, Albania
}

lekairma@gmail.com

\author{
Doi:10.5901/mjss.2015.v6n1s1p127
}

\begin{abstract}
This article briefly discusses the effects of the role of peer and social interaction in adolescent academic achievement. The purpose of this study is an attempt to give a personal contribution in the examination of the role between two different types of relationships between peers; frequent interactions and mutual membership in the group; and the decrease or the increase of the learning outcomes in terms of academic performance. To accomplish this purpose, it is formulated the following research question: Is there any effect of peer influence on academic achievement in adolescents of ages 12-15 years old? The study is a review of existing literature on the positive and negative aspects of the influence of peers regarding academic performance. Based on the data, reports and observations, it is shown that there is a need to understand the trend of the impact, to face research on social motivation as well as to conceptualize the impact of peer relations in an appropriate way. Empirical results show that peers create networks which lead to overestimation of the group effects on the traditional model and this causes them to change the objectives in the academic achievements. Furthermore, it is observed that adolescents have an increased social motivation which is followed by a decrease of academic motivation; this consequence causes the demonstrations of the inability in academic areas in school. These results are understandable if the acceptance of the adolescent from the peer group is one of the measurement keys of positive and negative experiences at school. Future examinations could examine the motivational dynamics which will contribute to the academic development of sustainable assets and developing an academic identity by allowing in this way the adolescents to use the group in interest of academic success. This study serves not only to the family but to the school and society at the same time. If society and education understand the negative impact of peer group pressure, are more likely to prevent it and more prepared to help the adolescent to handle this fact.
\end{abstract}

Keywords: adolescents, friendship, motivation, peer influences, academic performance

\section{Introduction}

Understanding the way that social interactions affect the academic achievement is very important for parents, educators and the education system as a whole. In particular, academic achievements and corresponding levels of educational attainment tend to predict the average income of an individual which are necessary to ensure the life. Given this, the elimination of the negative effects of peer academic achievement represents an important contribution to education reform. Academic performance is an important indicator of school success. It is not only associated with high school completion, but also the ability to successfully take into adult roles, to achieve economic self-sufficiency, and to become a productive member of the community (Hodgkinson, 1991; U.S. General Accounting OfGce, 1993).

Extensive literature emphasizes that peer group influences social and academic development and that these influences are transformed into a startup of formal education (Anthony Pellegrini, 1992). Influences and motivations for all sorts of behaviors of adolescents, including study habits and academic personal development, do not come only from their peers, but also by their parents, teachers and others with whom they establish contacts (Kathryn Wentzel, 1998). But, because of the time that many adolescent spend every day with his friends or her coevals the impact can be substantial.

Studies on the impact of peer orientation and group rates in adolescents are a lens with which to examine the academic achievement. From another point of view, previous studies have investigated the impact of peer rejection on academic achievement. Research shows that peer rejection at all time points (in the present and in the past) have negative effects on school attendance, and in external or inner behavioral problems (DeRosier, Kupersmidt, and Patterson, 1994).

\section{Conceptual Issues in the Assessment of the Effects of Peer Group}

Effects of peer group academic performance are also examined through (Brock and Durlauf, 2001) and Moffitt (2001), 
who stress in particular the impact on the educational context. This is particularly true in classrooms and schools, where researchers have increasingly recognized that academic achievement may be affected by social concerns (Juvonen, 2006; Juvonen \& Wentzel, 1996; Urdan \& Maehr, 1995). In fact, research shows that students' peer relationships may be associated with adaptive school outcomes, especially during periods of distress, such as transitioning to a new school (Connell \& Wellborn, 1991; Juvonen, 2006; Juvonen \& Wentzel, 1996; Ladd, 1990; Wentzel, Barry, \& Caldwell, 2004).

What this literature does not make clear, however, is when and why some peer relationships promote achievement, whereas others encourage disinterest and, in some cases, obstruct optimal achievement (Blumenfeld, 1992; Dweck, 1996; Graham, 1996; Graham, Taylor, \& Hudley, 1998; Juvonen, 2006; Juvonen \& Cadigan, 2002; Juvonen, Graham, \& Schuster, 2003). Despite relationships with other areas of adolescent functioning, peer influence is more likely to affect academic functioning abilities in adolescence. Research studies in the field of relationships among peers and academic achievements show that the effect of peer orientation in academic achievement is to be taken into account. Extreme orientation toward peers, involving willingness to ignore parents' rules, schoolwork, and one's own skills for the sake of popularity, has been linked to greater problem behavior in seventh, tenth, and twelfth grade and lower academic achievement in seventh and tenth grade (Fuligni, 2001).

\section{Academic Achievement and Peer Influence}

Peer influence on academic outcomes gradually becomes more dominant. Harris $(1998,2002)$ and Rowe $(1994)$ maintained that peer groups have an even stronger influence than that of parents, although that extreme position has been refuted by other researchers (Berk, 2005).

Doing part in peer groups is a key stage of development and creation of adolescent identity (Santor, 2000). Many see their peers as role models. These models can be a source of motivation or lack thereof.

There are two kinds of models, the positive and the negative: Positive models, refer to individuals who have achieved outstanding success and are widely expected to improve others to pursue excellence and similar negative patterns that refer to individuals who have experienced disaster and is widely expected to motivate people to take steps necessary to avoid similar unpleasant result (Lockwood dhe Kunda, 2002). Also, we can say that it is the pressure of their peers which can lead teens to unhealthy and unsafe behaviors and in their academic achievements.

Peer pressure may be defined as the insistence and encouragement of the same age group individuals to make or force the individual to do something (Santor, Messervey \& Kusumakar, 2000). Pressure coevals is associated with wrong decisions, rebellion and humor fluctuations, which will lead to a poor academic performance, because of the fact that adolescents are not cooperative in the process of learning outcomes and as a result their school results fall weakly. (Sharry, 2004). Contrary to popular belief, not all peer influence is negative. Spending more time with peers does not always translate into trouble (Lingren, 1995). Positive peer influence on academic performance depends on adolescent self-identity, self-esteem and self-reliance.

The peer group is a source of affection, sympathy, understanding, and a place for experimentation. It is always possible for parents to talk with school counsellors and professionals to help with the problem. Allen, Porter, McFarland, Marsh, and McElhaney (2005) report that adolescents who were well-liked by many peers displayed higher levels of ego development and secure attachment, as well as better interactions with their best friends. It was found that associating with friends who have a positive affect toward school enhanced students' own satisfaction with school, whereas associating with friends who have a negative affect toward school decreased it (Ryan, 2000). Less motivated or disengaged students, on the other hand, "are passive, do not try hard, and give up easily in the face of challenges" (Skinner \& Belmont, 1991). From a social competency perspective, it is likely that students who have difficulty establishing themselves in a peer group may also have academic difficulties in school (Wentzel, 1991). While the differences are more observed between adolescents that are neglected and those who are rejected. Wentzel and Asher (1995) find that socially neglected early adolescents may fare better than average in terms of academic achievement.

Experiencing peer rejection can produce heightened anxiety (e.g., worry over being teased or left out) which interferes with concentration in the classroom and impedes children's acquisition and retention of information (Nansel, Overpeck, Pilla, Ruan, Simons-Morton, \& Scheidt, 2001; Sharp, 1995). This finding emphasizes the importance of which elements are most important in affecting the academic arrivals. However, the percentage of teenagers friends with academic orientation itself is not predictive of academic achievement (Fuligni, 2001). This may be an evidence of lack of peer influence academic achievement, or a need to investigate other aspects of friendship beyond the similarity in academic success (Fuligni, 2001). 


\section{Motivation and Academic Performance}

Expectations of others and the climate surrounding adolescent determines their willingness to learn and when these two are not motivating it leads in poor academic performance (Mullins, 2005). Maintaining high motivation affects psychological and social functioning and facilitates academic performance and positive perception of the school (Gilman \& Anderman, 2006). The perception of peer support is positively related with school outcomes and adjustment (Buhs \& Ladd, 2001), academic motivation (Altermatt \& Pomerantz, 2003; Furrer \& Skinner, 2003; Wentzel, McNamara-Barry, \& Caldwell, 2004) and prosocial behaviours (Wentzel, 2004). As Kamil (2003) points out, "Motivation and engagement are critical for adolescent readers.

If students are not motivated to read, researches shows that they will simply not benefit from reading instruction". In general terms, student motivation refers to a student's willingness, need, desire and compulsion to participate in, and be successful in, the learning process (Bomia, 1997). Adolescents will take on the task of learning better only if they have sufficiently compelling reasons for doing so. When students feel that they are cared for and treated with respect by their teachers and peers, they are more likely to develop greater confidence in their academic abilities (Goodenow, 1993; Murdock \& Miller, 2003).

Students' sense of academic self-concept influences how they behave, how they feel, and how they think-the three dimensions of engagement (Eccles, 2009), and indeed, student confidence in personal academic ability has been shown to predict level of school engagement and task involvement ( Eccles \& Wigfield, 2002; Schunk, 1996). Students who experience emotional support and motivation from teachers and peers are more likely to attach greater value to learning in school (Roeser, 1998).

\section{Friendship Selection as a Source of Influence}

Friendship refers to a close, mutual and voluntary relationship. Friends have been described most often with respect to their qualities and functions (Newcomb \& Bagwell, 1996; Parker \& Asher, 1993). It has been shown that having friends promotes individuals' well-being and academic success (Hartup \& Stevens, 1997; Wentzel, 2004) and buffers against maladjustment (Bukowski, 1996; Hodges, Boivin, Vitaro, \& Bukowski, 1999; Laursen, Bukowski, Aunola, \& Nurmi, 2007). Friendship interactions are particularly important with regard to social integration because adolescent are more likely to stay in school when they feel comfortable and connected to other adolescent with similar interests and aspirations (Tinto 1975).

This phenomenon of similarity among friends is known as homophily and is seen on a variety of characteristics, including academic characteristics (Altermatt and Pomerantz, 2003; Kindermann 2007; Prinstein and Dodge 2008; Ryan 2000). In addition, studies have reported that having a good friend or companion who appreciates your academic achievements, serves as a positive factor to achieve motivation. They also tend to be engaged in and even excel at academic tasks more than those who have peer relationship problems (Rubin, Bukowski, \& Parker, 2006; Wentzel, 2005). In this regard, the selection of friendship serves as a purpose to achieve academic development (Resnick, Ireland, \& Borowsky, 2004).

By choosing to associate with particular peers, adolescents select a social context which exposes them to a particular set of values, behaviours, and opportunities. Whether or not students select friends with similar academic goals, they may become more similar over time via socialization. Peers are "the single most potent source of influence," affecting virtually every aspect of development—cognitive, affective, psychological, and behavioral (Astin, 1993). Student interaction with friends can positively influence overall academic development, knowledge acquisition, analytical and problem-solving skills, and self-esteem (Kuh 1993).

It has been pointed out that peer selection and influence from peers are complementary processes that work together to produce the adolescent's social context. Adolescents acquire friends who are similar to them, and they also appear to acquire new friends who are rather similar to their old friends (Caspi, 1993). Based on the prevailing view in the existing literature on friends and academic adjustment (Altermattand Pomerantz 2003; Brown, 2008; Kindermann 2007; Ryan 2000), we hypothesize that selection processes occur among friends for achievement of the goals.

\section{Conclusions}

The purpose of the literature review is not only to understand the impact of coevals regarding academic performance and socialization among teenagers, but also a form of analysis which serves as a research and practice for the future. Wentzel and Caldwell (1997) provide further evidence that students' relationships with peers are an important influence 
on their scholastic achievement. Clearly emerges from the literature that the relationship with classmate in fact, has a relatively strong impact on the daily functioning of the adolescent's academic performance.

The summary of literature also stresses that there are a variety of studies already carried out in relation to this area, which have some discrepancies between them, but that may be due to the diversity of samples used, and variability assessment of the instruments construction or representation of multidimensional studies. In this study it is emphasized simultaneously that the influence of peer academic performance is not always negative. Groups where they belong are necessary for the growth and development of adolescents, and therefore the teens should be encouraged to make positive choices about peers and work to combat their negative impacts.

Given the relationship between peer group acceptance and academic performance, schools and society must carefully consider policies that restrict students from participating in sports and social activities that encourage relationships with peers because of poor academic performance. Studies suggest that children who actively participate in social activities with peers feeling healthier than more isolated children (Vilhjalmsson, 1994).

From the study it seems clear that socialization in groups is not a fad or a trend, but it is a necessity to stay. For this reason, the impact of coevals will be a phenomenon to be studied over time. Helping adolescents to navigate in their social environment during school is a key to improving their academic functioning both concurrently and into the future. We know that as peer problems become more chronic or severe, adolescent's risk for later negative outcomes, including academic failure, significantly increases (DeRosier, 1994). Schools should deemphasize competitive and individualistic work and promote cooperation (Ames, 1992; D. W. Johnson, 1970). Cooperative goal structures require that students interact while working on academic assignments, thus building relationships while making academic progress.

As the results, the more successful students are in building positive peer relationships, the more likely these students are to achieve. It is also recommended that additional research examine the influence of peer group acceptance on the academic performance of adolescents in the context of other potential influences, including the nature of relationship, the academic culture in at home, and the support and encouragement that students receive from teachers at school.

\section{References}

Allen, J. P., Porter, M. R., McFarland, F. C., Marsh, P., \& McElhaney, K. B. (2005). The two faces of adolescents' success with peers: Adolescent popularity, social adaptation, and deviant behavior. Child Development, 76(3), 747-760.

Altermatt, E. R., \& Pomerantz, E. M. (2003). The development of competence-related and motivational beliefs: An investigation of similarity and influence among friends. Journal of Educational Psychology, 95, 111-123.

Ames, C. (1992). Classrooms: Goals, structures, and student motivation. Journal of Educational Psychology, 84, 261-271

Anthony Pellegrini, "Kindergarten Children's Social-Cognitive Status as a Predictor of First-Grade Success," Early Childhood Research Quarterly, Vol. 7 (1992), pp. 565-577.

Astin, A. W. (1993b). What Matters in College? Four Critical Years Revisited (1st Ed.). San Francisco: Jossey-Bass.

Blumenfeld, P. C. (1992). Classroom learning and motivation: Clarifying and expanding goal theory. Journal of Educational Psychology, $84,272-281$.

Bomia, L., Beluzo, L., Demeester, D., Elander, K., Johnson, M., \& Sheldon, B. (1997).

The Impact of Teaching Strategies on Intrinsic Motivation. Champaign, IL: ERIC Clearinghouse on Elementary and Early Childhood Education

Brock WA, Durlauf SN. 2001. Interactions-based models. In Handbook of Econometrics, Heckman JJ, Leamer EE (eds). North-Holland: Amsterdam; 3297-3380.

Bukowski, W. M., Newcomb, A. F., \& Hartup, W. W. (1996)(Eds.), The company they keep - Friendship in childhood and adolescence. Cambridge, US: Cambridge University Press

Caspi, A. (1993). Why maladaptive behaviors persist: Sources of continuity and change across the life course. In D. C. Funder, R. D. Parke, C. Tomlinson-Keasey, \& K. Widenen (Eds.), Studying lives through time:Personality and development (pp. 209-230). Washington, DC: APA

Connell, J. P., \& Wellborn, J. G. (1991). Competence, autonomy and relatedness: A motivational analysis of self-system processes. In M. R.Gunnar \& L. A. Sroufe (Eds.), Minnesota Symposium on Child Psychology (Vol. 22, pp. 43-77). Hillsdale, NJ: Erlbaum.

De Rosier M, Kuperdmidt JB, Patterson CJ (1995). Children's academic and behavioral adjustment as a function of chronicity and proximity of peer rejection. Child development. 1994;65(6):1799-1813

Dweck, C. S. (1996). Social motivation: Goals and social-cognitive processes. A comment. In J. Juvonen \& K. R. Wentzel (Eds.), Social motivation: Understanding children's school adjustment (pp. 181-195). New York: Cambridge University Press.

Eccles, J. S., \& Wigfield, A. (2002). Motivational beliefs, values, and goals. Annual Review of Psychology, 53, $109 \mathrm{e} 132$.

Eccles, J. S. (2009). Who am I and what am I going to do with my life? Personal and collective identities as motivators of action. Educational Psychologist, 44, 78e89

Fuligni, A. J., Eccles, J. S., Barber, B. L., \& Clements, P. (2001). Early Adolescent Peer Orientation and Adjustment During High School. 
Developmental Psychology, 37(1), 28-36.

Goodenow, C. (1993). Classroom belonging among early adolescent student: relationships

to motivation and achievement. Journal of Early Adolescence, 13, 21e 43.

Hartup, W. W., \& Stevens, N. (1997). Friendships and adaptation in the life course. Psychological Bulletin,121, 355-370.

Hodgkinson, H. (1991). Reform versus reality. Phi Delta Kappan.73 (1), 9-16

Furrer, C., \& Skinner, E. (2003). Sense of relatedness as a factor in children's academic engagement and performance. Journal of Educational Psychology, 95, 148 - 162.

Graham, S. (1996). What's "emotional" about social motivation? A comment. In J. Juvonen \& K. R. Wentzel (Eds.), Social motivation: Understanding children's school adjustment (pp. 346-360). New York: Cambridge University Press

Graham, S., Taylor, A., \& Hudley, C. (1998). Exploring achievement values among ethnic minority early adolescents. Journal of Educational Psychology, 90, 606-620.

Harris, J. R. (1998). The nurture assumption: Why children turn out the way they do. New York: Teacher College Press.

Hodges, E. V. E., Boivin, M., Vitaro, F., \& Bukowski, W. M. (1999). The power of friendship: Protection against an escalating cycle of peer victimization. Developmental Psychology, 35,94-101.

Juvonen, J. J. (1996). Self-presentation tactics promoting teacher and peer approval: The function of excuses and other clever explanations. In J.Juvonen \& K. Wentzel (Eds.), Social motivation: Understanding children's school adjustment (pp. 43-65). New York: Cambridge University Press.

Juvonen, J. J., \& Cadigan, R. J. (2002). Social determinants of public behavior of middle school youth: Perceived peer norms and need to be accepted. In F. Pajares \& T. Urdan (Eds.), Adolescence and education, Vol. 2: Academic motivation of adolescents (pp. 277-297). Greenwich, CT: Information Age.

Juvonen, J. J., Graham, S., \& Schuster, M. (2003). Bullying among young adolescents: The strong, weak, and troubled. Pediatrics, 112, 1231-1237.

Juvonen, J. J. (2006). Sense of belonging, social bonds, and school functioning. In P. A. Alexander \& P. H. Winne (Eds.), Handbook of educational psychology (pp. 655-674). Mahwah, NJ: Erlbaum.

Kamil, M. L. (2003). Adolescents and literacy: Reading for the 21st century. Washington, DC: Alliance for Excellent Education.

Kindermann, T. (2007). Effects of naturally existing peer groups on changes in academic engagement in a cohort of sixth graders. Child Development, 78, 1186-1203.

Kuh, G. D. (1993). In Their Own Words: What Students Learn Outside the Classroom. American Educational Research Journal

Ladd, G. W. (1990). Having friends, keeping friends, making friends, and liked by peers in the classroom: Predictors of children's early school adjustment. Child Development, 61, 1081-1100.

Laursen B., Bukowski, W. M., Aunola, K., \& Nurmi, J.-E. (2007). Friendship moderates prospective associations between social isolation and adjustment problems in young children. Child Development, 78, 1395-1404.

Lingren, H. G. (1995). Adolescence and peer pressure. Retrieved January 24, 2004 from http://www.experimentresources.com/sociallearning-theory.html

Lockwood,P., Jordan, C.H., \& Kunda, Z. (2002). Motivation by positive or negative role models: Regulatory focus determines who will best inspire us. Journal of personality and social psychology, 83(4), 854-864.

Moffitt, T. E., A. Caspi, M. Rutter, and P. A. Silva. 2001. Sex Differences in Antisocial Behaviour. Cambridge, MA: Cambridge University Press

Murdock, T. B., \& Miller, A. D. (2003). Teachers as sources of middle school students' motivational identity: variable-centered and person-centered analytic approaches. Elementary School Journal, 103, 383e399.

Nansel, T. R., Overpeck, M., Pilla, R. S., Ruan, W. J., Simons-Morton, B., \& Scheidt, P. (2001). Bullying behaviors among U.S. youth: Prevalence and association with psychosocial adjustment. Journal of the American Medical Association, 285(16), 2094-2100.

Newcomb, A. F., \& Bagwell, C. L. (1996). The developmental significance of children's friendship relations. In W. M. Bukowski, A. F. Newcomb, \& W. W. Hartup (Eds.), The company they keep: Friendship during childhood and adolescence (pp. 289-321). New York: Cambridge University Press.

Prinstein, M. J. (2008). Introduction to the special section on suicide and non-suicidal self-injury: A review of unique challenges and important directions for self-injury science. Journal of Consulting and Clinical Psychology, 76(1), 1-8.

Ryan, R. M., \& Deci, E. L. (2000). Self-determination theory and the facilitation of intrinsic motivation, social development, and wellbeing. American Psychologist, 55, 68-78.

Resnick, M. D., Ireland, M., \& Borowsky, I. (2004). Youth violence perpetration: what protects? What predicts? Findings from the National Longitudinal Study of Adolescent Health. Journal of Adolescent Health, 35(424), e1-e10.

Rubin, K. H., Bukowski, W. M., \& Parker, J. G. (2006). Peer Interactions, relationships, and groups. In N. Eisenberg, W. Damon, \& R. M. Lerner (Eds.), Handbook of child psychology: Vol. 3. Social, emotional, and personality development (6th ed., pp. 571-645). Hoboken, NJ: John Wiley \& Sons

Santor, D. A., Messervey, D., \& Kusumakar, V. (2000). Measuring peer pressure, popularity, and conformity in adolescent boys and girls: Predicting school performance, sexual attitudes, and substances abuse. Journal of Youth and Adolescence, 29(2), 163-182

Sharry, J. 2004. Counseling Children, Adolescents, and Families. London: Sage Publications.

Smith, P.K., and S. Sharp. 1995. The problem of school bullying. In School bullying: Insights and perspectives,ed.P.K.Smith, andS.Sharp,1-19.London:Routledge

Schunk, D. H. (1996). Goal and self-evaluative influences during children's cognitive skill learning. American Educational Research 
Journal, 33, 359e382.

Tinto, V. (1975). Dropout From Higher Education: A Theoretical Synthesis of Recent Research. Review of Educational Research

U.S. General Accounting Office (GAO). (1993). School-linked human services: A comprehensive strategy for aiding students at-risk of school failure. (GAO/HR-94-21). Washington DC: U.S.GAO

Wentzel, K.R., \& Asher, S.R. (1995). The academic lives of neglect rejected, popular, and controversial children. Child Development, 66, $754-763$

Wentzel, K.R., \& Caldwell, K. (1997). Friendships, peer acceptance nd group membership: Relations to academic performance in middle school. ChildDevelopment, 68(6), 1198-1209.

Wentzel, K. R.(1998). Social Relationships and Motivation in Middle School: The Role of Parents, Teachers, and Peers.Journal of Educational Psychology, 90(2), 202-209.

Wentzel, K. R., Barry C. M., \& Caldwell,K. A. (2004). Friendships in middle school: Influences on motivation and school adjustment. Journal of Educational Psychology, 96,195-203.

Vilhjalmsson, R. (1994). Effects of social support on self-assessed health in adolescents. Joumal of Youth and Adolescence. 23, 437451 